\title{
COXEN Score 2
}

National Cancer Institute

\section{Source}

National Cancer Institute. COXEN Score 2. NCI Thesaurus. Code C128199.

A score of 2 on the COXEN Sensitivity Scale. 